brazilianpoliticalsciencereview

ART I CLE

\title{
Soft Power, Hard Aspirations: the Shifting Role of Power in Brazilian Foreign Policy*
}

\author{
Marcelo M. Valença \\ Universidade do Estado do Rio de Janeiro, Brazil \\ Gustavo Carvalho \\ PhD Candidate, University of Toronto, Canada
}

\begin{abstract}
Journalists and policy analysts have highlighted the emergence of Brazil as a regional power. However, little attention has been paid to its foreign policy strategies. Brazil's rise to prominence in world politics represents the historical culmination of a foreign policy featuring two main strategies - persuasion and consensus building - both of which emphasise the use of soft power. We analyse four current foreign policy initiatives: the campaign for a permanent seat on the UNSC; the development of a nuclear submarine; Brazil's leadership of the UN peacekeeping mission in Haiti; and government support for Brazilian multinationals. We suggest a growing tension between these initiatives and the two strategies identified above. These initiatives reflect the view current among some policymakers that if Brazil is to rise as a global power it must play by the rules of great power politics.
\end{abstract}

Keywords: Brazilian foreign policy; United Nations Security Council; nuclear submarine; BNDES.

(*) http://dx.doi.org/10.1590/1981-38212014000100021

A previous version of this paper was presented at the 2012 International Studies Association Annual Conference in San Diego, USA. The authors would like to thank Leticia Pinheiro, Maria Regina Soares de Lima, Octavio Amorim Neto, Miriam G. Saraiva, Andres Malamud, Marcos Alan Ferreira, Nukhet Ahu Sandal, and the three anonymous reviewers with the Brazilian Political Science Review, for their invaluable comments and suggestions. Any errors are entirely our own. Marcelo M. Valença would also like to thank the Fundação de Amparo a Pesquisa do Rio de Janeiro (FAPERJ) for the post-doctoral scholarship that partially funded this research. 
$\mathrm{n}$ the past two decades, and particularly during the administration of President Luiz Inácio Lula da Silva, Brazil has been more involved in regional and international issues. Building on strong economic growth over the period, the country has raised its profile, winning the bid to host the 2014 FIFA World Cup and the 2016 Olympic Games. Moreover, due to its size and increasing economic clout, Brazil has been identified as a leader in South America, and one of the most substantial players in the Global South (MORAN, 2012; SWEIG, 2011; SWEIG and SPEKTOR, 2011)1. Brazil's new prominence in foreign affairs can be understood as the historical culmination of a foreign policy that has traditionally been built around two endeavours: to achieve (i) autonomy and (ii) a significant role in international politics (SARAIVA and VALENÇA, 2011, p.100).

These long-term goals, however, have been consistently challenged at different times by the relative weakness of Brazil's hard-power capabilities (HAMANN, 2012a, p. 02; KENKEL, 2013, p. 276). In the absence of more robust material means, the Brazilian government's main strategies have been directly connected with what, after Joseph Nye $(2003,2004 a, 2004 b)$, came to be defined as 'soft power', i.e. "the ability to attract and persuade rather than coerce" (NYE, 2003, p. 66). Soft power works as a complement to hard power and although it may include aspects also identified with forms of economic power, at its core it is based on the attractiveness and legitimacy of a country's culture, political ideals, values, and policies (NYE, 2003, p. 66; NYE, 2004b). For this reason, Brazilian foreign policy has mainly followed strategies that deploy non-material aspects of power (HAMANN, 2012b, p. 71): consensus-building initiatives, diplomacy and persuasion. Considering its history, recourse to soft power seems to make sense in view of Brazil's interests, goals and resources.

This is not to suggest that Brazil has been unable or unwilling to resort to more traditional forms of hard power, and it has exerted its military power in the past when core national interests have been in jeopardy (HAMANN, 2012b, p. 73). Nevertheless, Brazilian policymakers have privileged soft-power strategies in

\footnotetext{
${ }^{1}$ We use the term Global South as it is used by international organisations such as the United Nations Office for South-South Cooperation. It refers broadly to developing states (including, but not limited to the G-77 countries) that share common social, cultural and economic aspects that facilitate South-South Cooperation. For further details, please refer to <http://ssc.undp.org/content/ssc.html>.
} 
conducting Brazilian foreign policy (BURGES, 2008; VIGEVANI, FAVARON, RAMANZINI and CORREIA, 2008). Soft power became even more important in the 1990s, when the country reengaged with a range of multilateral forums (BURGES, 2008; CERVO and BUENO, 2008, p. 463; SARAIVA, 2010) in an attempt both to intensify trade and political dialogue with South America and the Global South (KENKEL, 2013) and to gain leverage in dealings with the major powers.

Despite growing awareness of Brazil, particularly in global media outlets, little attention has been paid to the traditional strategies it has used in its foreign policy. Scholars, pundits and policy experts have usually cast Brazilian foreign policy as weak or reluctant, particularly in cases where United States or European public opinion and foreign policy elites demanded or encouraged decisive action to curb human rights violations in politically unstable regions of the globe. Brazil's voting record on the UN Human Rights Council (where it has repeatedly abstained on human rights violations in Iran), its attempt to mediate a nuclear deal between Iran and the United States, and its votes on the Security Council challenging intervention in Libya and elsewhere, are just a few examples (MARIN, 2011; MORAN, 2012; SOTERO, 2011; SWEIG, 2011; SWEIG and SPEKTOR, 2011).

This narrow perspective has led analysts and commentators to miss the motivations behind Brazilian foreign policy, among them its traditional noninterventionist stance. More importantly, they have also overlooked a recent shift in Brazilian policymakers' understanding of the uses of power, away from the more traditional strategies used in Brazilian foreign policy and towards hard power.

This article begins by explaining the paradigms - Americanism, globalism, pragmatic institutionalism, and autonomism ${ }^{2}-$ that have guided Brazilian foreign policy in the past, to explore the role that persuasion and consensus-building have played in Brazil's long-standing emphasis on soft-power discourse. It then discusses four 'new' initiatives that mark the shift away from these foreign-policy traditions. It looks first at Brazil's campaign for a permanent seat on the United Nations Security Council (UNSC), its development of a nuclear-powered

\footnotetext{
2 The use of paradigms to frame Brazilian foreign policy is a didactic mechanism designed to categorise and facilitate understanding of its development and main characteristics. The typology presented in this article reflects some of the most recurrent uses and does not constitute a consensus among analysts.
} 
submarine, its leading role in the United Nations Stabilisation Mission in Haiti (MINUSTAH) and the use of its publicly-owned development bank (BNDES) to support Brazilian multinational corporations. It concludes by highlighting the growing tension between these initiatives and official Brazilian discourse, which is still reliant on the long-standing traditions and strategies of persuasion and consensus building.

\section{Brazilian foreign policy paradigms}

Brazilian foreign policy has traditionally been structured around two main endeavours. The first is to build political and economic autonomy at the international level (PINHEIRO, 2004, p. 07). The second - closely related to the endeavour to achieve autonomy and originating in a shared understanding in foreign policy circles of Brazil's identity in relation to the world and its Latin American neighbours - is to find a substantial role in international politics. Accordingly, one of the main characteristics of Brazil's foreign policy is its relative continuity, despite the socio-economic changes the country has undergone since independence (MALAMUD, 2011a, p.90; SARAIVA, 2010).

This is not to suggest that the different groups in power have always shared the same views on foreign policy, but the disagreements - whether originating from regime change or the circumstances surrounding a given government - have not entailed major change of course nor affected the key themes of foreign policy (SARAIVA and VALENÇA, 2011, p. 100). 'Relative continuity' means that Brazilian foreign policy has been based on general guidelines and relatively stable understandings of the content of Brazil's national interests. In this sense, its foreign policy can be analysed by way of paradigms, i.e., groups of concepts that highlight certain variables and empirical observations and allow certain behavioural trends to be explained. As a methodological tool for analysing foreign policy strategies, paradigms thus contribute in three ways (CERVO, 2003, pp. 07-08). Firstly, paradigms can highlight the values and cultural factors that give the members of a certain political community a sense of belonging. Secondly, analysts use paradigms as a way to make sense of and explain political elites' perceptions and interests at any given time. Paradigm changes usually represent changes in other sets of preferences, such as political and 
cultural values or economic strategies. Thirdly, paradigms presuppose political arrangements, and thus explain medium- and long-term trends or breaks with previous models, in turn affecting longer-term decision-making processes and strategic choices ${ }^{3}$.

From such an analysis, it is possible to identify four guiding paradigms in Brazilian foreign policy: Americanism, Globalism, Pragmatic Institutionalism, and Autonomism. They describe positions that have shifted depending on the government in power, but have not changed those long-held understandings of Brazil's priorities and goals in any fundamental sense.

The Americanist paradigm is considered to be the first systematically manifested in Brazilian foreign policy. It developed mainly in the 1890s during the early years of the Republic in direct counterpoint to the more European-centric stance of the recently-ousted monarchy (SILVA, 1995, pp. 97-103). The Americanists - represented by key figures in the foreign policy establishment of the time, such as Joaquim Nabuco, Salvador de Mendoça, and the Baron of Rio Branco - correctly identified the United States as a rising power and argued that the best way to increase Brazil's bargaining position vis-à-vis the major powers, while at the same time increasing its power resources and profile in the hemisphere, was to secure a position as a preferential partner of the United States in Latin America (HIRST, 2009a, pp. 20-25; PINHEIRO, 2004, pp. 14-16) ${ }^{4}$.

The Globalist paradigm became a real alternative to Americanism in Brazilian foreign policy circles in the 1950s. Its rise was connected with important changes both in Brazilian society and abroad. Rooted in the classic Realist tradition, Globalists argued that in an anarchic environment Brazil should pursue its own national interests as it deemed expedient, without tying itself up in any permanent partnerships (LIMA, 1994, pp. 27-46). Moreover, Brazil should diversify its partners in order to broaden its policy space, gain leverage in

\footnotetext{
${ }^{3}$ Please see Cervo (2003) for a comprehensive discussion of the study of paradigms and its use as an analytical tool to understand and explain Brazilian foreign policy.

${ }^{4}$ Some authors point to the existence of two different approaches to the Americanist paradigm: the pragmatic approach, focussing on relationships seen as contributing to national development; and the ideological approach, highlighting the convergence of values and beliefs between the US and Brazil (the ideological similarities being considered more important than any potential outcome resulting from the partnership). Please see Lima (1994), Pinheiro (2000 and 2004), Ricúpero (1995) and Silva (1995) for a more detailed explanation of these approaches to the Americanist paradigm.
} 
international negotiations and boost its power capabilities, particularly in relation to the United States.

The Globalist paradigm was manifest, first and foremost, in the set of policies known as Brazil's Independent Foreign Policy (Política Externa Independente, PEI). This new understanding of Brazil's interests, autonomy and, ultimately, its foreign policy discourse, charted a theoretically neutral course for its foreign policy in relation not only to the bipolar West-East dispute during the Cold War, but also to the broader non-aligned movement, which Brazil did not join (SILVA, 1995, pp. 110-111). At the same time, the PEI allowed Brazil to take a stance more in line with the new North-South dichotomy and rooted in social and development issues (HIRST, 2009a, p. 34). This explains certain foreign policy positions that may seem puzzling or even contradictory, such as the diplomatic support that Brazil's right-wing military dictatorship gave, in the 1970s, to leftist Angolan liberation guerrillas fighting in the war of independence against Portugal.

The 1990s brought yet another paradigm change in Brazilian foreign policy. Economic crisis, combined with the political problems that culminated in the impeachment of President Fernando Collor de Mello in 1992, led to the collapse of both Americanism and Globalism, which had alternated as the mainstays of Brazilian foreign policy for almost a century (HIRST, 2009b; PINHEIRO, 2004, pp. 56-57; SARAIVA and VALENÇA, 2011, pp. 104). Furthermore, Brazil's redemocratisation in the 1980 s paved the way for new civil society actors to participate in foreign policy formulation, affecting traditional decision-making processes and broadening views and perspectives inside the Brazilian government.

Vice-president Itamar Franco, who replaced Collor de Mello, made the Mercosur and achieving regional leadership his foreign policy priorities (BURGES, 2008; VÁZQUEZ and RUIZ, 2009, p. 34). These choices laid the foundations for the two new paradigms still prevalent today: Pragmatic Institutionalism and Autonomism. They propose that Brazil should forge stronger bonds with its neighbours and that these partnerships will in turn help the country establish itself as a regional leader and inch closer to the main international decision-making circles. Instead of relying on self-sufficiency, as in the past, Brazil should work to establish its autonomy and build up its international stature by participating in international institutions and by building political and economic linkages with 
Latin America, the Global South and the broader international community (LAMPREIA, 1998; PINHEIRO, 2004, p. 77).

Pragmatic Institutionalism was the main foreign policy paradigm during the two presidential terms of Fernando Henrique Cardoso (1995-2002). It was marked by the gradual, limited and controlled opening of the Brazilian economy to the international market, adherence to international liberal standards and membership in international organisations such as the WTO (CERVO and BUENO, 2008, p. 463; SARAIVA, 2011). It differed from both Americanism and Globalism in the importance it placed on multilateralism as a strategy for legitimation in international politics. For this reason, advocates of Pragmatic Institutionalism made Brazil's entry onto the international stage conditional on respect for normative principles and values such as the right to socio-economic development. Brazil was thus able to strengthen its endeavour to gain autonomy while being seen as an active and responsible member of the international community (LAMPREIA, 1998; MALAMUD, 2011b, p. 06).

The achievements of the Pragmatic Institutionalism paradigm allowed the administration of President Luiz Inácio Lula da Silva (2003-2010) to make further efforts to project Brazil as a global player (LIMA, 2008). The Autonomist paradigm maintained the strategies developed by Pragmatic Institutionalism (CERVO and BUENO, 2008, p. 492), but assumed a revisionist and more defensive stance, arguing that Brazil should look beyond South America and attempt to influence other countries in the Global South (GONÇALVES, 2011, p. 25; KOCHER, 2011, pp. 171-176). This strategic shift has been facilitated by the international political and economic context of the past decade. The turbulence and changes of the period created some room for change in international institutions without completely disrupting the international order (ALMEIDA, 2008; LIMA, PINHEIRO and HIRST, 2010), providing broader political space, which Brazil has used to improve its international standing.

It is interesting to note that the paradigms above not only share these two endeavours - for policy autonomy and a more substantial role for Brazil in the international system; they also reveal a lack of symmetry between the country's power capabilities and its international aspirations. Given Brazil's lack of hard power, the various paradigms have historically advocated foreign policy strategies 
that rely instead on bandwagoning with global or prominent powers (here, particularly the Americanist paradigm, in its many forms) on participating actively in international political organisations and other forums where Brazil could mitigate the importance of hard power capabilities while claiming to represent a different kind of leadership. The next section will discuss Brazil's reliance on soft power.

\section{Soft power strategies: persuasion and consensus building}

Although both of these foreign policy endeavours suggest that Brazilian policy-makers were historically concerned with power projection and accumulating hard power, Brazilian foreign policy has mostly been marked by the use of non-material components of power (HAMANN, 2012b, p. 72) and particularly by strategies such as persuasion and consensus building (BURGES, 2008, pp. 65-66). Accordingly, the concept of 'soft power' developed and systematised by Joseph Nye in the early 2000s offers a useful way to understand the strategies and motivations behind Brazilian foreign policy until the rise of the Autonomist paradigm, during the Lula da Silva administration.

Nye was careful to view power in context, since one cannot refer to power without considering the political context in which it is used. Soft power may have advantages and may be more effective in certain contexts, while 'hard power' most commonly, but not exclusively, represented by military power - may not be completely fungible or transferable from one context to another (BALDWIN, 1979, pp. 165-166). Moreover, soft power strategies may be less contested and less costly to those who use them, meaning they can be employed even by states lacking the means to acquire large militaries or sophisticated weaponry. Smaller countries may be more attractive to others for their culture or shared values, and can also be more nimble and effective in promoting them in international forums, since soft power can be managed through, and even amplified by, international institutions. Extrapolating on the concept, soft power can even be said to dilute the traditional trade-off between 'power' and 'plenty', as its strategies tend to draw on, and benefit from, economic growth and domestic programmes traditionally identified with 'plenty'.

Although Nye was more concerned with what he understood to be a recent 
transformation in how power is conceptualised and how states use it, soft power strategies have arguably been in use for a long time. The paradigms discussed above highlight how Brazilian foreign policy elites have historically used those strategies in endeavours to consolidate the country's regional leadership and its international importance. Soft power suits the conditions and vulnerabilities of a country like Brazil: a global player, but not a global power, which has great international aspirations, but historically has been able to accumulate, and employ in its foreign policy, only limited hard power capabilities.

It must be clear that this is not to claim that Brazil's opting for soft power is merely a 'strategy of the weak'. Brazilian political elites have employed hard power when they regarded the country's core interests as at stake (HAMANN, 2012b, p.73; MALAMUD, 2011b, pp. 04-05). One of the most salient cases was the war with Paraguay in the 1860s-1870s. True, such events were the exception, not the rule (LAFER, 2001), and Brazil did not have at its disposal the hard power capabilities of great powers such as Great Britain, but our point is broader than that.

The Brazilian option for soft power also fits with a broader domestic political discourse on Brazil's place in South America, and a shared perception in foreign policy circles of its role as a non-interventionist leader in the Global South (HAMANN, 2012b; KENKEL, 2013). These views have been enshrined in principles, such as non-intervention and peaceful resolution of international disputes, that have been present in Brazilian political discourse since the first republican constitution of 1891, and in Brazil's contemporary promotion of the principle of "responsibility while protecting" in humanitarian interventions (HAMANN, 2012a). Furthermore, Brazilian political elites' use of soft power has gone beyond merely attempting to forestall international aggression or defend the country's positions from other, more powerful states; it has been used to support and even improve Brazil's position in relation to other powers.

Unsurprisingly, the use of persuasion as a soft power strategy presupposes a shared understanding, on the part of the actors involved, of the identity and motivations of the state that is wielding that power. At a minimum, the states that are to be influenced by soft power strategies must accept that there is something desirable, or not entirely detrimental, about the proposals coming from 
the influencing state. In that regard, three historical and two recent factors have contributed to strengthening Brazil's soft power and its tradition as a noninterventionist power in Latin America and, more broadly, in the Global South (HAMANN, 2012b; KENKEL, 2013).

The first historical factor is the series of treaties that Brazil's monarchy, and subsequently the young republic, signed with many of its neighbours to settle boundary disputes and establish its territory. As a consequence of these treaties, Brazil has avoided the kind of disputes and simmering tensions that are still common in the region and weigh down on some of its neighbours' relations. The second historical factor is the Brazil's traditional constitutional and legal commitment to multilateralism and non-interventionism abroad, as mentioned above. The third and final historical factor is the country's participation in international organisations, and its actively promoting the institutionalisation of trade and integration in Latin America.

The Americanists who came to power with the Brazilian republic were ardent supporters of Pan-Americanism. Brazil also became a member of the League of Nations and a non-permanent member of its Security Council, and participated in all the regional integration initiatives of the 1950s and 1960s (CAMARG0, 1993). More recently, Brazil has pushed for the South American integration project, of which Mercosur and Unasur are the two latest manifestations (MALAMUD, 2011b, pp. 06-07). It is also important to note that these initiatives have been characterised by consensus- or unanimity rule-based voting and decision-making mechanisms, which may have helped reinforce Brazil's image and soft power in South America.

The first recent factor is the success story of the Brazilian social-economic model, which is loosely inspired in the European social-democratic welfare model. Its foundations were laid by the Cardoso administration, but it was revamped and consolidated by the Lula da Silva administration with cash-transfer programs such as the Bolsa Família. Some scholars also draw attention to the stability of Brazil's democratic regime since the end of the military dictatorship in the 1980s (HIRST, $2009 \mathrm{~b})$. The second factor is the charisma and positive image carefully constructed and maintained on the continent by President Lula da Silva, who subtly promoted the Brazilian model in the region as an alternative to the more radical one 
proposed by President Hugo Chávez of Venezuela (SANT'ANNA, 2009; Lulismo v. Chavismo 2011; SENA, 2012).

These perceptions may, of course, not be grounded in reality or may exaggerate the positive aspects of Brazilian foreign policy without taking appropriate stock of its downside. We should not take Brazil's leadership in South America for granted (LIMA et al., 2010). Yet it is interesting to note that - aside from some analyses that stress fears of a new Brazilian imperialism, usually connected with lingering resentments from old hard-power episodes, such as the War with Paraguay and the annexation of Acre State by Brazil from Bolivia (GUZMÁN, 2009; SANT'ANNA, 2009) - there has been considerable goodwill towards Brazil in the region, particularly over the past thirty years.

As already mentioned, Mercosur and Unasur are the most recent examples of Brazil's employing persuasion and consensus-building strategies to project an image as a trustworthy representative of the continent and potential leader of the Global South (HIRST, 2009a, p. 07; SARAIVA and VALENÇA, 2011, p. 117). Brazil's influence - beyond its participation in the G-20 - also spread beyond the region following the creation of political and economic blocs such as the IBSA Political Forum and the BRICS initiative. These initiatives have enabled Brazilian policymakers to propagate the official discourse of consensus building outside of South America and to showcase Brazil as a possible mediator in the dialogue between the North and the Global South. By resorting to soft power strategies that emphasise Brazilian values and an ability to create consensus and attract other countries towards its positions, Brazil has been able to act as a representative of its peers, while strengthening its international status by showing that it shares some interests and values with the North.

Although relatively successful thus far, Brazil's use of soft power at this new global level faces two important challenges. The first is posed by the contradictory position of a country that presents itself as one of the main speakers for the Global South, while also striving to be recognised as a potential member of the North (VALENÇA, 2010, pp. 12-13). The second challenge is posed by recent foreign policy initiatives taken during the Lula da Silva and Rousseff administrations that brush aside the soft-power approach of the past and emphasise hard-power dimensions instead, contradicting the official discourse 
sustained by government officials such as Celso Amorim, Minister of Defence in the Rousseff administration and formerly Foreign Minister in the Lula administration (KENKEL, 2013), who reaffirmed the traditional role of soft power strategies by arguing that Brazil aims to build peace on the continent and is not engaged in an arms race with potential regional rivals (AMORIM, 2012, pp. 270-271).

The next section will examine these initiatives: Brazil's bid for a permanent seat on the UNSC, its leadership in the MINUSTAH mission, the development of a nuclear submarine and the use of the BNDES development bank to promote Brazilian influence abroad. These initiatives are important as they mark a inflexion point in Brazilian foreign policy during the Lula and Rousseff administrations and have been promoted by Brazilian officials as crucial stepping stones in the quest for autonomy and recognition at the international level. They are also interconnected. Given the time and space constraints and the preliminary nature of our enquiry, we treat each initiative as a separate idiographic case study, as defined by Levy (2008, p. 02). Therefore, the focus here is on interpretive and qualitative analysis with the goal of understanding each case better, but without intending to generalise or form broad hypotheses applicable across time and place.

\section{Recent initiatives in Brazilian foreign policy}

The Brazilian bid for a more prominent position on the UNSC is the reflection of a long-standing desire among Brazilian foreign policy elites (ARRAES, 2006; MALAMUD, 2011b, p. 09). After World War I, Brazil aspired to play a distinguished role in the League of Nations as the representative of South America. With the withdrawal of the United States and the organisation's subsequent predominantly Eurocentric arrangement, it was granted only a non-permanent seat on the League Council. However, despite the unsuccessful claim to a permanent seat on the League Council, Brazil's elites still regarded their country as holding status distinct from that of other Latin American countries and believed that further involvement with peace and war issues would enhance its international position.

Later, during World War II, Brazil sent a small expeditionary force to Europe, making it the only South American country to be directly involved in the conflict. Brazil also contributed logistical support to the war effort, mainly by 
exporting natural resources and leasing air bases to the United States. In the view of Brazilian policymakers, their country's participation in the war should guarantee it a privileged position in post-war political arrangements (NETO, 2013, pp. 427,448 ) and Brazil was, in fact, eventually invited by the United States to participate in the United Nations as one of the permanent members of the UNSC. The proposal was rejected by the Soviet Union and Great Britain, but as a remedial gesture Brazil was invited to become a non-permanent member of the Council (VARGAS, 2011, p. 85). Currently, Brazil ranks among the states that have participated most often on the Council (UNSC, 2012a).

The campaign for a permanent seat returned to Brazil's foreign policy agenda in the late 1980s, as the country re-democratised after 21 years of military rule (VARGAS, 2011, p. 87). Brazilian policymakers believed that, following the end of the Cold War, changes in the international political environment would highlight the need for a new political arrangement on the UNSC, which had been structured to reflect the distribution of power in the immediate post-war environment and had never been fully reviewed since. They also believed that Brazil's return to civilian rule would make its bid more feasible (VARGAS, 2011).

João Augusto Vargas (2011, pp. 88-89) summarises these renewed Brazilian aspirations in four broad arguments that ultimately are connected to the traditional use of soft power in Brazilian foreign policy. They maintain that (i) reform of the UNSC is necessary to maintain the legitimacy of the contemporary international order; (ii) Brazil is important as a growing political and economic power; (iii) Global South states should be part of the UNSC and Brazil's presence in the forum would contribute to representing them; and (iv) Brazilian society itself is interested in taking on a role as a global player.

Thus, from a purely rhetorical point of view, Brazilian claims to a permanent seat on the UNSC are connected to the idea that its participation would legitimise the council, allow new manifestations of political influence and challenge the tradition of military powers as the guarantors of the international order. As the argument goes, Brazil is not concerned to showcase its military capabilities nor to guarantee core national interests above the interests of the international community (VARGAS, 2011). Furthermore, with a permanent seat, Brazil could enhance its role as a mediator in international disputes and as a facilitator in the 
on-going dialogue between the Global South and the North. Brazil could also be expected to work in line with its own foreign policy traditions, promoting nonviolent strategies in conflict resolution and state building. Seen in this way, the peacekeeping experience in Haiti, which explicitly supports the very structures and principles present in the UN Charter, represents a sample of Brazil's proposals and capacity as a different kind of international actor. The "Responsibility while Protecting" initiative also reflects the preference for a normative approach rather than the traditional mechanism of international intervention predicated on the use of force to protect civilians in armed conflicts. The emphasis on conflict prevention highlights the importance of international norms and collective action to maintaining international order (HAMANN, 2012c, p. 28).

Still, despite their emphasis on soft power, Brazilian policymakers have de facto acted on very different assumptions about the role of the UNSC. Given the UNSC's continuing importance to the maintenance of international order, and the monopoly that its permanent members have on the decision-making process, Brazilian policymakers have quietly worked on the belief that would-be permanent members of the UNSC need to develop their hard power in order to be able to engage in military interventions and thus meet any potential challenges to international peace and order (FERREIRA, 2012).

In the light of these perceptions, it is not surprising that the Brazilian government has focused on acquiring and improving Brazil's hard power capabilities in recent years. These concerns have become pervasive in policymakers' official pronouncements and in government-sponsored documents and reports. Roberto Mangabeira Unger - a Brazilian intellectual and political theorist, who was a tenured professor at Harvard University before becoming Minister for Strategic Affairs in the Lula administration - was quoted in 2008 by Reuters/O Globo as saying that Brazil's National Defence Strategy (Estratégia Nacional de Defesa, END), designed to guide Brazilian policies with a view to national defence, might be seen by others as "the instrument of an arms race". However, he also considered that, if that were the case, it was crucial to foster a debate in Brazilian society on the country's "ambitions" and the "sacrifices that are necessary to transform ambitions into reality" (Plano de defesa sofrerá críticas, prevê Mangabeira Unger, 7 Sept. 2008). 
Taking their cue from the END and Minister Unger, Brazil's armed forces have pushed for more material and financial resources and new weapon systems. A series of reports prepared by the Brazilian military, focusing on a range of programs for technological capacitation and reform, highlight the tension between the official soft power discourse and the country's hard power ambitions. For instance, in a recent report on a programme titled Braço Forte (Strong Arm), the Brazilian Army states that, as a short-term goal, the programme should lead to the development of hard power capabilities that would allow the Army to act as a deterrent to any potential threats in the region, as well as to "first-rank powers". More interestingly, it also states clearly that the programme's medium- and longterm goals should be to help the Army enhance its "power projection" capabilities (PERI, 2009, p. 08).

The goal of being able to project power is also one of the Brazilian Navy's justifications for pursuing its nuclear submarine programme. Over the coming decade, Brazil aims to build four new diesel-electric propelled submarines, and one nuclear-powered submarine. France is transferring technology for the submarine hull, and Brazil will use its own technology for the nuclear reactor (MARTINS FILHO, 2012). In very general terms, both Brazilian policymakers and journalists have pointed out that a nuclear submarine would be invaluable as a deterrent factor to protect the increasingly important offshore oil fields along Brazil's coasts (CAVAS, 2009; MARTINS FILHO, 2012, pp. 306-307; MONTEIRO and FERNANDES, 2009; RODRIGUES, 2009). However, Navy officers have been keen to play the geopolitical card by pointing out that all current permanent members of the UNSC have nuclear submarines. For instance, in a 2009 interview, a retired admiral pointed explicitly to the geopolitical uses of a nuclear submarine: "When Brazil becomes the sixth (country with a nuclear submarine), it will be much bigger as a nation from both military and strategic points of view. It will have solid means to claim a (permanent) seat on the Security Council" (RODRIGUES, 2009). This perception was corroborated by President Rousseff in a recent speech in which she affirmed that the development of a nuclear submarine represented the acquisition of not only important hard power capabilities, but also industrial capabilities that Brazil would need in the future in order to meet its needs, especially for social development. Thus, as suggested here, official soft-power discourse ambiguously 
supports Brazil's aspiration to traditional power (POLITO, 2013).

According to some specialists, it is not entirely clear whether construction of a nuclear submarine will actually bring immediate strategic advantages to Brazil. They are costly to build and operate and conventional submarines can perform many of the same functions with lower maintenance costs. The main differential though is again geopolitical, since one of the concrete impacts of a nuclear submarine would be to bump Brazil ahead of its Latin American neighbours in any potential race for a seat on the UNSC (TAYLOR, 2009). The same could be said of how the specialised, heavy industrial infrastructure Brazil is developing in order to build a nuclear submarine relates to its meeting future social needs. Despite President Rousseff's claims, the connection is tenuous at best.

Similar concerns with hard power underlie Brazil's leadership of the MINUSTAH mission in Haiti, which showcases both the country's capacity to act effectively as a regional police power (MALAMUD, 2011b, p. 10) and its foreign policy coherence, all the while bolstering the claim to a permanent seat on the UNSC. Set up in 2004, the MINUSTAH's main responsibilities included dissolving the Haitian Army (which was considered to be a spoiler in the peace process), eliminating guerrilla and criminal groups, and restoring public services and security in the country.

Brazil has been involved in international peacekeeping since the 1930s, when it joined peacekeeping initiatives under the League of Nations (KENKEL, 2013, p. 281). It first participated in a UN mission in 1957, sending 600 soldiers to the UNEF I after the Suez Crisis (FONTOURA, 2005, pp. 209-215). Since then, it has participated in 26 UN peacekeeping operations, mostly with observer status (AGUILAR, 2005; FONTOURA, 2005, pp. 215-217; Peacekeepers brasileiros que atuaram em missões de paz na ONU recebem homenagem nesta sexta-feira, 2011a; OMMATI, 2012). From 1957 to 1999, Brazil deployed 11,300 military personnel (including infantry, medical personnel and observers) and 287 police observers (FONTOURA, 2005, p. 217), and is currently participating in 9 of the 17 ongoing UN peacekeeping missions. As Table 1 shows, most military and police personnel deployed by Brazil in past operations have been limited to observer roles. In many missions, Brazil did not even deploy military personnel, opting instead to send civilian electoral observers and healthcare professionals. 
Table 01. Brazilian involvement in UN peacekeeping operations

\begin{tabular}{|c|c|c|c|c|c|}
\hline $\begin{array}{l}\text { Brazilian } \\
\text { Involvement }\end{array}$ & Mission & Host Country & Military Personnel & $\begin{array}{c}\text { Police } \\
\text { Personnel }\end{array}$ & $\begin{array}{c}\text { Civilian } \\
\text { Personnel }\end{array}$ \\
\hline $1957-1967$ & UNEF & Egypt & 6,300 infantry & 0 & 0 \\
\hline 1960 & ONUC & Congo & $\begin{array}{l}179 \text { (pilots/ support } \\
\text { personnel) }\end{array}$ & 0 & 0 \\
\hline 1962 & UNSF & $\begin{array}{l}\text { West New } \\
\text { Guinea }\end{array}$ & 2 observers & 0 & 0 \\
\hline $1965-1966$ & DOMREP & $\begin{array}{l}\text { Dominican } \\
\text { Republic }\end{array}$ & 1 observer & 0 & 0 \\
\hline $1965-1966$ & UNIPOM & India/Pakistan & 10 observers & 0 & 0 \\
\hline 1989-1991 & UNAVEM I & Angola & $\begin{array}{l}16 \text { observers } \\
1 \text { medical unit }\end{array}$ & 0 & 0 \\
\hline 1989-1992 & ONUCA & Central America & 34 observers & 0 & 0 \\
\hline 1997-1999 & UNSCOM & Iraq & $\mathrm{N} / \mathrm{A}$ & $\mathrm{N} / \mathrm{A}$ & $\mathrm{N} / \mathrm{A}$ \\
\hline 1991-1995 & ONUSAL & El Salvador & 63 observers & 16 observers & 5 \\
\hline 1991-1995 & UNAVEM II & Angola & $\begin{array}{c}63 \text { observers } \\
14 \text { medical personnel }\end{array}$ & 39 observers & 4 \\
\hline 1993-1994 & ONUMOZ & Mozambique & $\begin{array}{c}170 \text { paratroopers } \\
48 \text { observers }\end{array}$ & 66 observers & 16 \\
\hline \multirow[t]{2}{*}{ 1993-1994 } & UNOMUR & Ruanda/Uganda & $\begin{array}{c}10 \text { observers } \\
3 \text { medical personnel }\end{array}$ & 0 & 0 \\
\hline & UNOMIL & Liberia & 3 observers & 0 & 0 \\
\hline 1992-1995 & UNPROFOR & $\begin{array}{c}\text { Former } \\
\text { Yugoslavia }\end{array}$ & 90 observers & 23 observers & 0 \\
\hline 1993 & UNTAC & Cambodia & 0 & 0 & 19 \\
\hline 1995-1997 & UNAVEM III & Angola & $\begin{array}{l}\text { 4,174 (infantry, } \\
\text { engineers, medical } \\
\text { personnel, observers } \\
\text { and officers) }\end{array}$ & 48 observers & 0 \\
\hline 1995-1996 & UNCRO & Croatia & 2 observers & 1 observer & 0 \\
\hline 1995 & UNPREDEP & Macedonia & 5 observers & 0 & 0 \\
\hline 1996-1998 & UNTAES & East Slavonia & 9 observers & 2 observers & 0 \\
\hline 1997-1998 & MONUA & Angola & $\begin{array}{c}20 \text { observers } \\
15 \text { medical personnel }\end{array}$ & 39 observers & 0 \\
\hline 1996-1999 & UNMOP & Croatia & 5 observers & 0 & 0 \\
\hline 1995 & UNFICYP & Cyprus & 20 observers & 0 & 0 \\
\hline 1994-1995 & MINUGUA & Guatemala & 39 observers & 37 observers & 0 \\
\hline 1994 & UNOMSA & South Africa & 0 & 0 & 12 \\
\hline 1999 & UNAMET & Timor Leste & 5 observers & 16 observers & $\mathrm{N} / \mathrm{A}$ \\
\hline 1999-today & $\begin{array}{l}\text { INTERFET, } \\
\text { UNTAET, } \\
\text { UNMISET }\end{array}$ & Timor Leste & $\begin{array}{c}120 \text { personnel } \\
\text { (average per year) }\end{array}$ & $\mathrm{N} / \mathrm{A}$ & $\mathrm{N} / \mathrm{A}$ \\
\hline 2004-today & MINUSTAH & Haiti & $\begin{array}{c}\text { 1,500 personnel } \\
\text { (average per } 6 \\
\text { months) }\end{array}$ & $\mathrm{N} / \mathrm{A}$ & $\mathrm{N} / \mathrm{A}$ \\
\hline
\end{tabular}

Sources: Fontoura (2005); Aguillar (2005), ABFI (2010)5.

\footnotetext{
${ }^{5}$ The data compiled in Table 01 are from various different sources. They all refer to the total number of troops, police officers and civilians officially deployed by the Brazilian government.
} 
Table 02. Summary of Brazilian personnel contribution to UN peacekeeping missions (average per year) - military observers, troops and police officers

\begin{tabular}{lc}
\hline Year & Number \\
\hline 2006 & 1,335 \\
2007 & 1,280 \\
2008 & 1,293 \\
2009 & 1,345 \\
2010 & 2,118 \\
2011 & 2,486 \\
2012 & 1,843 \\
2013 & 1,843 \\
2014 & $1,737^{*}$ \\
\hline
\end{tabular}

Source: UN Peacekeeping (2014).

Note: * From January to June.

Although Brazil deployed more troops than any other country in UNEF, UNAVEM III, and UNMISET, Haiti was the first time the UNSC appointed it to command a peace operation, and Brazilian policymakers have considered it an opportunity to show that, due to its different approach to peacekeeping, Brazil is able to handle peace-keeping and international security tasks of greater magnitude and difficulty (FERREIRA, 2012).

Two factors help explain Brazil's leadership of MINUSTAH. The first is that the United States found no incentive to send troops to Haiti, given the turbulent history of its involvement in Haiti's domestic politics and its inability to stabilise the country in previous interventions. The same can be said of France and other European states. The ability of African and Asian countries to supply MINUSTAH's needs was limited by the geographical distance from Africa and Asia, combined with the on-going peace operations on those continents. Despite its tradition of supporting Chapter VI missions, Brazil was invited to take the leading role in the mission since it contributed the most troops to the operation (FERREIRA, 2012; UNSC, 2012b).

The second factor relates closely to the first. Accepting a major role in MINUSTAH was seen as compatible with Brazil's role as a power in the South American region and in the Global South (MALAMUD, 2011b, pp. 19-20). Due to the global powers' limited interest in MINUSTAH, Brazil stepped up and agreed to command the mission. Until then, save for the Suez Peninsula missions, Brazil had deployed troops only when it was clearly in the national interest or there were 
affinities with the host country (BRACEY, 2012, p. 316; KENKEL, 2013, p. 282). This shift from Brazil's secondary participation in earlier UN missions to its active leadership role at MINUSTAH underlines the country's own perception of its changing international role and the limitation it faces for lack of material resources.

Brazil's leadership did promote social involvement by MINUSTAH soldiers, who offered medical services to civilians, distributed food and participated in community events. The importance given to this social involvement is reflected in the size of the Brazilian Engineering Battalion (the largest unit in MINUSTAH) and the activities it engaged in. The engineers were tasked with rebuilding bridges, installing power generators and reconstructing roads and streets in order to restore Haiti to normality (O Brasil no Haiti: o esforço da reconstrução, 2011b). This closer contact improved relations between the troops and the local population, making for easier acceptance of the foreign occupation forces and lending them legitimacy. The soccer game in Port-au-Prince between the Brazilian national team and Haiti also helped waylay any suspicions towards MINUSTAH and fostered the impression that Brazil was actually there to help the population, not to keep local protégés in power.

This understanding underpins the Brazilian Army's approach to fulfilling the mission mandate. The first stage of MINUSTAH did focus on security in order to allow the mission to act and move freely in Haiti. In tandem with the security measures, however, MINUSTAH also aimed to legitimise its presence in the country. Previous UN missions to Haiti had tried to create a secure environment to ensure peace and the return to normal of the country's political processes, but neglected the roots of the conflict or the socioeconomic dynamics that could spoil the outcomes of the intervention.

Even so, beneath the discourse and outward appearance of soft power, MINUSTAH also revealed a more traditional, power-politics side to Brazil's role in peacekeeping operations. Accordingly, the Brazilian presence in Haiti may be understood as a catalyst for change in the capabilities and doctrines of the armed forces (KAWAGUTI, 2006, pp. 130-132). Moreover, the tactics employed in patrolling Haitian cities are being replicated in Brazilian cities, especially in important cities, such as Rio de Janeiro. For instance, the patrolling of Rio's favelas 
during the 2008 elections was inspired in the successful experience at Cité de Soleil.

Brazil's national development bank, the Banco Nacional de Desenvolvimento Econômico e Social (BNDES), is another means the country has used to boost its influence in South America (BURGES, 2008, p. 77). The bank was set up in 1952 to support and promote the development of a strong private sector in Brazil. Acting as a development bank, the BNDES has provided capital for investments in infrastructure, heavy industry and agriculture, in a historical context of international capital scarcity and low rates of gross capital formation.

In view of its mission and objectives, the BNDES has focused, for most of its history, on financing investments in Brazilian companies operating in the domestic market. Since the early 1990s, however, it has also started to act as an "eximbank", financing Brazilian exports, particularly of capital goods, to Latin America and other countries (BNDES, 2006; DOCTOR, 2014). More recently, the BNDES has also offered support to Brazilian-sponsored integration schemes such as Mercosur and Unasur. The bank opened its first international office in Montevideo, Uruguay, where since 2009 it has acted as the BNDES representative to Mercosur (BNDES, 2002).

These international initiatives are bound up with the traditional softpower conceptions of Brazilian foreign policy, but they are also part of a push to enter new markets and establish a zone of influence for Brazil in South America. This is particularly apparent in the internationalisation of certain Brazilian corporations, many of which were privatised during the 1990s, such as Embraer, an aircraft company, and Vale do Rio Doce, one of the world's biggest mining concerns (BNDES, 2006; BNDES, 2007). Much of this internationalisation process has targeted South America, a region which, unsurprisingly, Brazil's END has characterised as the country's main area of strategic interest.

The BNDES has been quite open about the reasons behind some of its goals, among them being "to offer growing support for the activities of Brazilian companies in South America, broadening strategic commercial ties" (BNDES, 2012). It has also been active in providing funding for Brazilian companies operating in Africa, particularly in the former Portuguese colonies of Angola and Mozambique (LEO, 2011). In economic terms, this should not be entirely 
surprising. As a result of the Mercosur and Unasur, South America is indeed one of the major markets for Brazilian companies, while Angola and Mozambique have longstanding historical ties with Brazil. On the other hand, it should be noted that BNDES's support for Brazilian companies active in South America and Africa fits well with the strategic goals of the END. Rather superficially, the term 'strategic' can be seen as reflecting these markets' importance to Brazilian companies and industry. However, it can also be read in terms of the more traditional geopolitical concerns of competition, survival, strategic control of trade relations with partners, development of a strong industrial sector and economic power more broadly, as exemplified by traditional realist scholars (CARR, 2001, pp. 108, 113, 124-129; MORGENTHAU, 1978, pp. 120-128) and newer approaches in Geoeconomics (SHEEHAN, 2005) - which are also present in the END. On that view, Latin America, together with the US, has traditionally been the biggest market for Brazilian manufactured goods and high-value-added products (BNDES, 2006): maintaining those markets is crucial to Brazilian industry not only in terms of sales and jobs, but also its very development and existence.

Over the past decade, Brazil has suffered from strong competition in both Latin America and Africa, especially from China, so it is important to understand the context behind the BNDES' move to support and finance "Brazilian multinationals" (COUTINHO, 2013; FIOCCA, 2006), such as Embraer, Vale do Rio Doce, Odebrecht and Gerdau, which have the size and capabilities to become competitive on a global scale. In a 2001 report on its strategic plan for the 5-year period beginning in 2000, the bank declared these goals very candidly: it was to "[support] Brazilian firms with international competitive potential, in order to turn them into global players, whilst pursuing the on-going process of trade liberalisation" (BNDES, 2001). In a recent interview, BNDES president, Luciano Coutinho, briefly discussed this policy, arguing further that the bank was preparing to shift focus towards the pharmaceutical and information technology sectors, which he thought had most potential going forward (COUTINHO, 2013).

\section{Final Considerations}

This article explores how Brazilian foreign policy adopts a discourse based on using soft power to achieve its long-term interests, but also emphasises political 
actions that assert the importance of hard power to consolidate its position in international politics. As a regional leader and candidate for a more prominent role in world politics, Brazil needs to balance carefully the two faces of power in order to be, at one and the same time, a legitimate representative of the Global South and a trusted ally of the North.

This tension is also closely related to another tension between the country's carefully cultivated identity as a non-interventionist multilateralist with deep roots on the Global South and its emerging aspirations to being the 'natural' leader of South America. The article points to possible explanations for these tensions. The changes in attitude, the new initiatives and the tensions discussed above show that Brazilian foreign policy is at a crossroads, representing a clash between different perceptions about its standing in the world. Brazil's newfound predominance has led policymakers to prepare the country for a larger role in world affairs - one in which great power and power politics rules are crucial and predominate. However, there is still strong reluctance on the part of foreign policy elites to abandon the traditional foreign policy stance and the old strategies of persuasion and consensus building.

Persuasion and consensus building, in this sense, reflect Brazil's attempt to be understood as a global power: they make for easier inclusion and acceptance in multilateral forums. Soft power, regarded as distinguishing Brazil from other global players, is felt to legitimise the country's actions, while enabling it to extend its area of influence beyond South America and establish Brazilian leadership over the Global South.

The four initiatives discussed corroborate such an argument. They show Brazil's efforts to be recognised as a global player and a regional leader and, at the same time, they highlight the tension existing between hard power and soft power in international politics. The argument goes that, even though official discourse glosses over the hard power dimension, there can be no engaging in politics and aspiring to a distinguished position unless that claim is supported in both dimensions.

As a result, the indecision and weakness perceived in Brazilian foreign policy, together with the tensions existing between discourse and practices and among different roles, can be understood as products of a readjustment in long- 
held perceptions about the country's identity. Brazil has been playing a complicated balancing act, attempting to reconcile its bid to become a consensual leader in South America and play its role as a legitimate representative of the Global South, while jockeying for a seat among greater powers. The projects presented here are commensurate with the country's ambitions, and send mixed signals to its South American neighbours.

Revised by Peter Lenny Submitted in November 2013 Accepted in August 2014

\section{References}

AGUILAR, Sergio Luiz Cruz (2005), A Participação do Brasil em Missões de Paz. In: Brasil em Missões de Paz, organised by Sergio Luiz Cruz Aguillar. São Paulo: Usina do Livro.

ALMEIDA, Paulo Roberto (2008), O Brasil como ator regional e como emergente global: estratégias de política externa e impactos na nova ordem internacional. Cena Internacional. Vol. 09, pp. 07-36.

AMORIM, Celso (2012), Uma visão brasileira do panorama estratégico global. Contexto Internacional. Vol. 33, № 02, pp. 265-275.

ARRAES, Virgílio (2006), O Brasil e a ONU de 1990 a nossos dias: das grandes conferências às grandes pretensões. In: Relações internacionais do Brasil: temas e agendas. Vol. 02, edited by Henrique Altemani e Antonio Carlos Lessa. São Paulo: Saraiva.

Associação Brasileira das Forças Internacionais de Paz da ONU - ABFI (2010), A Participação Brasileira nas Forças de Paz da ONU. < http://www.abfiponu.org.br/historia02.html>.

BANCO Nacional de Desenvolvimento Econômico e Social - BNDES (2002), Atuação Internacional

<http://www.bndes.gov.br/SiteBNDES/bndes/bndes_pt/Institucional/O_BND ES/A_Empresa/internacional.html>.

BANCO Nacional de Desenvolvimento Econômico e Social - BNDES (2006), International Bulletin

05. <http://www.bndes.gov.br/SiteBNDES/export/sites/default/bndes_en/Galeri as/Download/intl_bulletin05.pdf>.

BANCO Nacional de Desenvolvimento Econômico e Social - BNDES (2001), BNDES News, 2001. Essentials of the BNDES Strategic Plan for the Period 2000-2005. <http://www.bndes.gov.br/SiteBNDES/export/sites/default/bndes_en/Galeri 
as/Download/news-14.pdf>.

BANCO Nacional de Desenvolvimento Econômico e Social - BNDES (2007), International Bulletin 08. http://www.bndes.gov.br/SiteBNDES/export/sites/default/bndes_en/Galeria s/Download/intl_bulletin08.pdf>.

BANCO Nacional de Desenvolvimento Econômico e Social - BNDES (2012), The BNDES

Abroad. http://www.bndes.gov.br/SiteBNDES/bndes/bndes_en/Institucional/The_BN DES_Abroad/>.

BALDWIN, D. A. (1979), Power Analysis and World Politics: New Trends Versus Old Tendencies. World Politics. Vol. 31, № 02, pp. 161-194.

BRACEY, Djuan (2012), O Brasil e as Operações de Manutenção de Paz da ONU: os casos do Timor Leste e Haiti. Contexto Internacional. Vol. 33, № 02, pp. 315331.

BURGES, Sean W. (2008), Consensual Hegemony: Theorizing Brazilian Foreign Policy After the Cold War. International Relations. Vol. 22, № 01, pp. 65-84.

CAMARGO, Sonia (1993), A integração do Cone Sul. IRI-Textos.

CARR, Edwar Hallett (2001), The Twenty Years' Crisis, 1919-1939. New York: Perennial.

CAVAS, Christopher (2009), Brazil building fleet to protect resources. Defense News 04. <http://www.defensenews.com/story.php?i=4070498>.

CERVO, Amado L. (2003), Política Exterior e Relações Internacionais do Brasil: enfoque paradigmático. Revista Brasileira de Política Internacional. Vol. 46, № 02, pp. 5-25.

CERVO, Amado L. and BUENO, Clodoaldo (2008), História da política exterior do Brasil. Brasília: UnB.

COUTINHO, Luciano (2013), BNDES decide abandonar a política de criação de 'campeãs nacionais'. O Estado de São Paulo. April 22, 2013. <http://economia. estadao.com.br/noticias/economia-geral,bndes-decide-abandonar-a-politicade-criacao-de-campeas-nacionais,151356,0.htm>.

DOCTOR, M. (2014), Assessing the Changing Roles of the Brazilian Development Bank. Bulletin of Latin American Research.

FERREIRA, Carlos Enrique Ruiz (2012), Brasil como membro no permanente del Consejo de Seguridad de las Naciones Unidas en el período 2010-2011. Working Paper, Progama de Cooperación en Seguridad Regional, Friedrich Ebert Stiftung. 
FIOCCA, Demian (2006), O BNDES e a internacionalização das empresas brasileiras. May 29, 2006. <http://www.bndes.gov.br/SiteBNDES/export/sites/default/bndes_pt/Galeri as/Arquivos/empresa/download/apresentacoes/apresentacao_fiocca_firjan.p $\mathrm{df}>$.

FONTOURA, Paulo Roberto Tarrisse (2005), O Brasil e as operações de manutenção da paz das Nações Unidas. Brasília: Fundação Alexandre Gusmão.

GONÇALVES, Williams (2011), Panorama da política externa brasileira no governo Lula da Silva. In: A Política Externa Brasileira na Era Lula: um balanço. Edited by Adriano Freixo et al.. Rio de Janeiro: Apicuri.

GUZMÁN, Sandra B. (2009), La nueva doctrina: ¿América para los brasileños?, November 29, 2009. El Tiempo. <http://www.eltiempo.com/archivo/documento/CMS-6701928>.

HAMANN, Eduarda P. (2012a), The Protection of Civilians in Armed Conflict and Brazil's Responsibility while Protecting. NOREF Policy Brief. <http://www.peacebuilding.no/Themes/Protection-ofcivilians/Publications/The-protection-of-civilians-in-armed-conflict-andBrazil-s-responsibility-while-protecting>.

HAMANN, Eduarda P. (2012b), Brazil and R2P: A Rising Global Player Struggles to Harmonise Principles and Practice. In: The Responsibility to Protect - from evasive to reluctant action? The Role of Global Middle Powers. Edited by Malte Brosig. Johannesburg: Hans Seidel Foundation, Konrad-Adenauer-Stiftung, Institute for Security Studies and South Africa Institute of International Affairs.

HAMANN, Eduarda P. (2012c), A "Responsabilidade de Proteger" e "ao Proteger": breve histórico e alguns esclarecimentos. In: O Brasil e a Agenda Global. Edited by Centro Brasileiro de Relações Internacionais (CEBRI). Rio de Janeiro: CEBRI, pp. 25-28.

HIRST, Monica (2009a), Brasil - Estados Unidos: desencontros e afinidades. Rio de Janeiro: Editora FGV.

HIRST, Monica (2009b), A presença do Brasil nos novos tempos da agenda interamericana. Análise de Conjuntura OPSA 5.

KAWAGUTI, Luis (2006), A República Negra: histórias de um repórter sobre as tropas brasileiras no Haiti. São Paulo: Globo.

KOCHER, Bernardo (2011), Os BRICS no governo Lula. In: A Política Externa Brasileira na Era Lula: um balanço. Edited by Adriano Freixo et al.. Rio de Janeiro: Apicuri.

KENKEL, Kai Michael (2013), Brazil's Peacekeeping and Peacebuilding Policies in 
Africa. Journal of International Peacekeeping. Vol. 17, pp. 272-292.

LAFER, Celso (2001), A Identidade Internacional do Brasil e a Política Externa Brasileira. São Paulo: Perspectiva.

LAMPREIA, Luis F. (1998), A Política Exterior de Fernando Henrique Cardoso. RBPI. Vol. 41, pp. 5-17.

LEO, S. (2011), Dilma revê estratégia para África. Valor Econômico (Rio de Janeiro), November $\quad 2011 . \quad<$ <ttp://publicidadevalordigital.valor.com.br/impresso/primeira-pagina/dilma-reve-estrategiapara-africa>.

LEVY, Jack S. (2008), Case Studies: Types, Designs, and Logics of Inference, Conflict Management and Peace Science, 25:1, 1-18.

LIMA, Maria Regina Soares; PINHEIRO, Leticia and HIRST, Monica (2010), A Política Externa Brasileira em Tempos de Novos Horizontes e Desafios. Análise de Conjuntura OPSA 12.

LIMA, Maria Regina Soares (1994), Ejes Analíticos y Conflito de Paradigmas en la Política Exterior Brasileña. America Latina Internacional. Vol. 01, pp. 27-46.

LIMA, Maria Regina Soares (2008), Brazil Rising. Multipolar World. International Politik. pp. 62-67.

LULISMO v. Chávismo: Latin American Politics (2011), The Economist. July 23 <http://www.economist.com/node/18988516>.

MALAMUD, Andres (2011a), Argentine Foreign Policy under the Kirchners: ideological, pragmatic, or simply Peronist? In: Latin America Foreign Policies: between ideology and pragmatism. Edited by Gian Lucca Gardini \& Paul Lambert. New York: Palgrave Macmillan.

MALAMUD, Andres (2011b). A Leader without Followers? The growing divergence between the regional and global performance of Brazilian foreign policy. Latin American Politics and Society. Vol. 53, pp. 1-24.

MARIN, D. C. (2011), Hillary Evita Apoiar Pleito do Brasil na ONU. O Estado de São Paulo. $\quad$ February, $24 . \quad$ São Paulo. <http://brasil.estadao.com.br/noticias/geral,hillary-evita-apoiar-pleito-dobrasil-na-onu-imp-,683857>.

MARTINS Filho, João Roberto (2012), O Projeto do Submarino Nuclear Brasileiro. Contexto Internacional. Vol. 33, № 02, pp. 277-314.

MONTEIRO, Tania, and FERNANDES, Adriana (2009), Jobim vai a Paris para fechar acordos militares com a França. O Estado de São Paulo. July 07, 2009, 
<http://www.estadao.com.br/noticias/nacional,jobim-vai-a-paris-fecharacordos-militares-com-a-franca,399037,0.htm>.

MORAN, M. (2012), Five Countries We Need: Brazil. Slate2. <http://www.slate.com/blogs/the_reckoning/2012/10/08/should_we_be_wo rking_more_with_brazil>.

MORGENTHAU, Hans (1978), Politics Among Nations: the struggle for power and peace. New York: Knopf.

NETO, L. (2013), Getúlio: Do Governo Provisório à Ditadura do Estado Novo (19301945). São Paulo: Companhia das Letras.

NYE, Joseph (2003), U.S. Power and Strategy After Iraq. Foreign Policy. July/August, pp. 60-73.

NYE, Joseph (2004a), Soft Power: the means to success in world politics. New York: Public Affairs.

NYE, Joseph (2004b), The Decline of America's Soft Power. Foreign Affairs. Vol. 83, p. 16.

O Brasil no Haiti: o esforço da reconstrução (2011b), Brazilian Ministry of Defence. <https://www.defesa.gov.br/arquivos/File/2011/mes02/livreto_haiti.pdf>.

OMMATI, Marcos (2012), CCOPAB: the Brazilian Center for Peace and Excellence. September 2012, 05, <http://dialogoamericas.com/en_GB/articles/rmisa/features/regional_news/2012/09/05/fe ature-ex-3471>.

PEACEKEEPERS brasileiros que atuaram em missões de paz na ONU recebem homenagem nesta sexta-feira (2011a), Brazilian Ministry of Defence. May 27, 2011. $<$ http://www.brasil.gov. br/noticias/arquivos/2011/05/27/militares-brasileiros-que-atuaram-emmissoes-de-paz-na-onu-recebem-homenagem>.

PERI, Enzo Martins (2009), Estratégia Braço Forte. <http://www.scribd.com/doc/16868607/bracoforte>.

PINHEIRO, Letícia (2000), Traídos pelo desejo: um ensaio sobre a teoria e prática da política externa brasileira contemporânea. Contexto Internacional. Vol. 22, № 02 , pp. 305-335.

PINHEIRO, Leticia (2004), Política Externa Brasileira (1889-2002). Rio de Janeiro: Jorge Zahar Editor.

PLANO de Defesa sofrerá críticas, prevê Mangabeira Unger (2008), O Estado de São Paulo. September 07, 2008, <http://www.estadao.com.br/noticias/nacional,plano-de-defesa-sofrera- 
criticas-preve-mangabeira-unger,237612,0.htm>.

POLITO, Rodrigo (2013), Dilma inaugura unidade de componentes do submarino nuclear brasileiro. Valor Econômico (Rio de Janeiro), March 01, 2013, <http://www.valor.com.br/politica/3028414/dilma-inaugura-unidade-decomponentes-do-submarino-nuclear-brasileiro>.

RICÚPERO, Rubens (1995), O Brasil, América Latina e os EUA desde 1930: 60 anos de uma relação triangular. In: Visões do Brasil: ensaio sobre a História e a inserção internacional do Brasil. Rio de Janeiro: Ed. Record.

RODRIGUES, Alexandre (2009), Submarino pode sair daqui a 12 anos: Marinha já encontrou terreno para sediar estaleiro que vai construir o primeiro modelo nuclear do Brasil. $O$ Estado de São Paulo. May 16, 2009 <http://www.estadao.com.br/noticias/impresso,submarino-pode-sair-daquia-12-anos,372147,0.htm>.

SANT'ANNA, Lourival (2009), Nacionalismo de esquerda regional explora 'imperialismo' do Brasil. O Estado de São Paulo. May 16, 2009 <http://www.estadao.

com.br/noticias/impresso,nacionalismo-de-esquerda-regional-exploraimperialismo-do-brasil,372115,0.htm>.

SARAIVA, Miriam Gomes (2010), A Política Externa Brasileira do Governo Lula: ideias e mudanças. Unpublished paper, presented at the $34^{\text {th }}$ ANPOCS Annual Conference.

SARAIVA, Miriam Gomes (2011), A América do Sul na Política Externa do Governo Lula: ideias e mudanças. In: A Política Externa Brasileira na Era Lula: um balanço. Edited by Adriano Freixo et al. Rio de Janeiro: Apicuri.

SARAIVA, Miriam Gomes and VALENÇA, Marcelo M. (2011), Brasil: potencia regional con intereses globales. Diálogo Político 4.

SENA, Fobomade (2012), Brasil toma el Consejo de Infraestructura de Unasur y relanza la IIRSA. Fobomade. February 16, 2012 <http://www.fobomade.org.bo/art-1589>.

SHEEHAN, Michael (2005), International Security: an analytical survey. London: Lynne Rienner.

SILVA, Alexandra de Mello e (1995), O Brasil no continente e no mundo: atores e imagens na política externa contemporânea. Estudos Históricos. Vol. 08, № 15, pp. 95-118.

SOTERo, P. (2011), Obama's Brazil Visit: Fresh Start to Ties? BBC News. <http://www.bbc.com/news/world-latin-america-12731912>.

SWEIG, J. (2011), Obama's Important Strides in Brazil. Council on Foreign Relations. 
<http://www.cfr.org/brazil/obamas-important-strides-brazil/p24445>.

SWEIG, J. and SPEKTOR, M. (2011), Mr. Obama, Meet the New Brazil. The New York

Times. March. New York. <www.nytimes.com/2011/03/19/opinion/19ihtedsweig19.html>.

TAYLOR, Paul D. (2009), Why does Brazil need nuclear submarines? Proceedings Magazine. 135/6/1,276, July, 2009. <http://www.usni.org/magazines/proceedings/2009-06/why-does-brazilneed-nuclear-submarines>.

UNITED Nations Department of Peacekeeping (UN Peacekeeping) (2014), Troops and Police Contributor Archives (1990-2013). <http://www.un.org/en/peacekeeping/resources/statistics/contributors_ archive.shtml>.

UNITED Nations Security Council - UNSC (2012a), Countries Elected Members of the Security Council. <http://www.un.org/en/sc/members/elected.shtml>.

UNITED Nations Security Council - UNSC (2012b), MINUSTAH Facts and Figures. <http://www.un.org/en/peacekeeping/missions/minustah/facts.shtml>.

VALENÇA, Marcelo M. and RAMOS, Paulo G. O. (2004), A Questão Nuclear nas Relações Diplomáticas Brasil-Estados Unidos. IRI-Textos.

VALENÇA, Marcelo M. (2010), Brazil: Inevitable Choices. IPRIS Lusophone Countries Bulletin. 02 January.

VARGAS, João Augusto C. (2011), Campanha Permanente: o Brasil e a reforma do Conselho de Segurança da ONU. Rio de Janeiro: Editora FGV.

VÁZQUEZ, Mariana and RUIZ, José Luis (2009), O Mercosul na Época de Lula e Kirchner: um balanço, seis anos depois. Nueva Sociedad - Especial em Português, pp. 33-49.

VIGEVANI, Tullo; FAVARON, Gustavo; RAMANZINI, Haroldo and CORREIA, Rodrigo (2008), O Papel da Integração Regional para o Brasil: universalismo, soberania e percepção das elites. RBPI. Vol. 05, pp. 5-27. 